\title{
Isotopic evidence of paleowaters in the Po sedimentary basin (Northern Italy)
}

\author{
Carlo Gorgni, Giovanni Martinelli and Gian Paolo Sighinolfi \\ Istituto di Mineralogia, Università di Modena, I-41100 Modena, Italy
}

(Received July 31, 1981: Accepted January 21, 1982)

\begin{abstract}
Stable isotopic composition and radiometric age were measured for groundwaters in the Emilia area of the Po sedimentary basin (Northern Italy). Waters from unconfined shallower aquifers, deep circulating continental waters and sodium chloride waters (relic waters) squeezed out from underlying marine formations during past geological events were considered. Waters from supposed confined aquifers (paleowaters) are usually depleted in $0-18\left(\delta^{18} 0<-10 \% 0\right)$ and their $\delta^{18} 0-\delta \mathrm{D}$ relationships are not consistent with their belonging to the present hydrological cycle. Isotope data on sodium chloride waters suggest mixing of relic saline waters with deep circulating continental waters. Processes affecting stable isotope composition of groundwaters in unconsolidated sediments are discussed. Oxygen isotope chemistry is considered to be a rather conservative parameter at least at low temperatures, thus able to give paleoclimatic information. Some ${ }^{14} \mathrm{C}$ age data on deep circulating groundwaters suggest permanence times within the aquifers greater than $15,000 \mathrm{yrs}$ in some cases. These data agree with paleoclimatological deductions in pointing out the presence of paleowaters in the Po sedimentary basin.
\end{abstract}

\section{INTRODUCTION}

Groundwaters in sedimentary basins are classified into two genetic types. The first one includes waters which are meteoric waters recycling at present and also those infiltrated during past geological times (e.g. Pleistocene or pre-Quaternary). The second type includes waters of marine origin trapped within the interstices of sedimentary layers, or sea waters which entered sediments after deposition during marine transgressive episodes. In the first category, we include fossil or relic waters previously considered in the group of connate waters as re-defined by WHITE (1965), i.e. waters that have been out of contact with the atmosphere for at least an appreciable part of a geological period. Fossil and relic waters usually are classed as paleowaters. According to the definition of FONTES (1980), these are groundwaters of past meteoric water origin and isolated from the cycling systems of groundwaters at present. Thus, on the basis of the generalized knowledge of climatological patterns in Europe in the late
Pleistocene, groundwaters with residence times greater than about 10,000yrs may be considered to be paleowaters.

Recent hydrological studies and chemical investigations of groundwaters of the Po sedimentary basin (Northern Italy) suggest very slow deep circulation patterns and consequent long residence times. Accordingly, the possibility of occurrence of paleowaters in the Po basin was investigated. The purposes of the present investigation are:

i) to determine whether paleowaters occur on the basis of isotope data and ${ }^{14} \mathrm{C}$ age patterns;

ii) to better define the chemical evolution and relationships among the various water types recognized;

iii) to draw paleoclimatological schemes for the area considered.

\section{Hydrological Patterns of THE AREA INVESTIGATED}

The groundwaters considered in the present 
study come from a central-southern part of the Po sedimentary basin (Northern Italy) which is bordered at the north and west by the Alps and at the south by the Apennine mountain chain. The basin, which had been a large gulf of the Adriatic sea until the late Tertiary, was filled with continental sediments from the Po river and from its Alpine and Apennine tributaries during the Quaternary. The area investigated (Fig. 1) extends from the Apennine border to the Po river and covers over $2,500 \mathrm{~km}^{2}$. The aquifers consist of a sequence of post-Pliocene unconsolidated continental sediments (calcareous gravel, sand and silt) mainly of Apennine derivation. This complex is confined between Mio-Pliocene marine formations below and Recent clay deposits above. Its thickness in the investigated area varies from a few hundred meters to several thousand meters depending on morpho-structural features of the basement (Bortolami et al., 1978). Main recharge areas for groundwaters circulating beneath this part of the valley are in the Apennine chain and in permeable surface sediments (such as the alluvial cones of rivers like the Panaro, Secchia, etc.) along the Apennine border. Hydrological studies (GASPERI and Pellegrini, 1969) show that groundwaters of the lowest, northern part

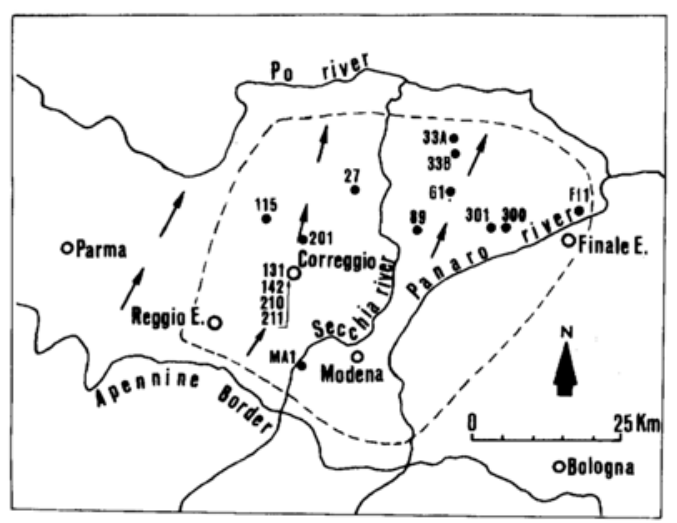

Fig. 1. The part of the Po plain investigated for groundwater circulation. Area delimited by broken line: area studied in detail showing the localization points of the samples isotopically analyzed. Arrows: general flow direction of phreatic waters. of the area (near the Po river) refer to a multiunit reservoir system formed by individual bodies of quite variable dimensions ranging from small lenses to widespread laterally persistent beds which cover many tens of square kilometers. The confining beds consist of illitic clays and silts whose permeability coefficient may range from almost zero to appreciable but low values.

\section{Previous Chemical Work}

Detailed hydrogeological descriptions and chemical data on groundwaters of the area have been reported elsewhere (SigHINOLFI et al., 1979; GoRGoNi et al., 1982a, b). On the basis of available data several different water types, characterized by different origin and/or circulation patterns, can be briefly described as follows:

a) Deep groundwaters near recharge areas They circulate at variable depths (up to several hundreds of meters) in coarse-grained alluvial sediments near the Apennine border. Chemically (Table 1, Fig. 2) they are characterized by a bicarbonate compositin and by the predominance of $\mathrm{Ca}$ among the cations. Sulphate ion is always present.

b) Shallower waters These are superficial waters which circulate at depths of a few tens of meters in the lowest part of the area, towards the Po river. They are not hydraulically con-

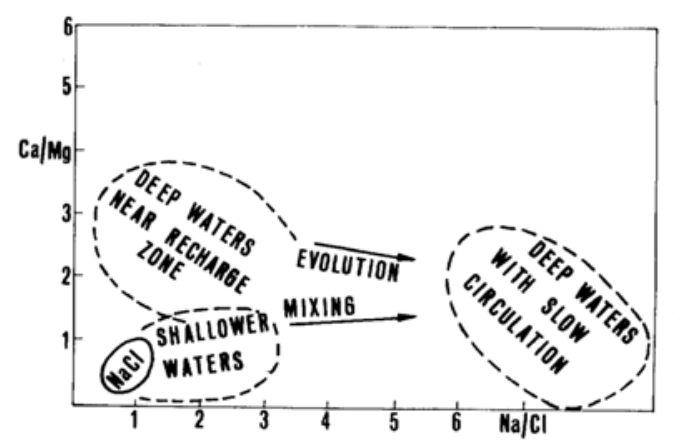

Fig. 2. Approximate compositional fields for groundwaters with supposed different permanence times within the aquifers. $\mathrm{NaCl}$ : sodium chloride waters and their mixing terms (from GoRGONI et al., 1982b). 
Table 1. Chemical characterization of the main types of groundwaters from the investigated area of the Po plain

Water type

(a) Deep waters near recharge zone

(b) Shallower waters

(c) Deep waters with slow circulation

(d) Sodium chloride waters

$\begin{array}{cc}\begin{array}{c}\text { Salinity } \\ (\mathrm{g} / \mathrm{l})\end{array} & \mathrm{pH} \\ 0.2-1.4 & 7.1-7.5 \\ 0.4-1.4 & 6.8-7.5 \\ 0.6-1.8 & 7.3-7.8 \\ 1.4-11 . & 7.4-8.1\end{array}$

$\begin{array}{cc}\text { anion } & \text { Chemistry } \\ \mathrm{HCO}_{3}>\mathrm{SO}_{4}>\mathrm{Cl} & \mathrm{Ca}>\mathrm{Na}>\mathrm{Mg}>\mathrm{K} \\ \mathrm{HCO}_{3}>\mathrm{SO}_{4} \geqslant \mathrm{Cl} & \mathrm{Ca} \geqslant \mathrm{Na}>\mathrm{Mg}>\mathrm{K} \\ \mathrm{HCO}_{3}>\mathrm{Cl} & \mathrm{Na}>\mathrm{Ca} \geqslant \mathrm{Mg}>\mathrm{K} \\ \mathrm{Cl}>\mathrm{HCO}_{3} & \mathrm{Na}>\mathrm{Mg} \geqslant \mathrm{Ca}>\mathrm{K}\end{array}$

nected with waters of type (a), being derived by infiltration of local meteoric or stream waters downwards in the near-surface layers. Chemically, they are similar to group (a), except for a more evenly balanced cationic composition (Fig. 2).

c) Deep waters with slow circulation patterns They circulate at variable depths (100 to 500 meters) in the lower plain area. Their chemistry is also rather variable, but usually they present a marked bicarbonate composition with sulphate ion present in minor amounts or completely absent.

d) Sodium chloride waters They are present at variable depths at the base of the freshwater reservoir system but locally they present interlayered within this system. Usually, they follow the structural patterns of the undelrying MioPliocene marine basement. Chemically, chloride content equals or exceeds the bicarbonate content, sulphate ion is generally absent and the salinity is highly variable, ranging from about 1 to more than $10 \mathrm{~g} / 1$. They are interpreted as originated by mixing of fossil or relic fluids squeezed out of the underlying marine formations with overlying continental waters.

Within the waters of group (c) some from the lower plain area drew our attention because of their peculiar composition. In comparison with most of other bicarbonate groundwaters, they are characterized by very high $\mathrm{Na} / \mathrm{Cl}$ ratios and rather low $\mathrm{Ca} / \mathrm{Mg}$ ratios (Fig. 2) and absence of sulphate. Besides, they generally present traces of $\mathrm{H}_{2} \mathrm{~S}$, thus indicating strongly reducing conditions at depth. Repeated analises on some of these waters indicated an extremely constant composition in time, thus apparently excluding any connection with surface waters affected by seasonal compositional fluctuations. Locally, a chemical stratification is noted in aquifers of various depths. For example, in the Correggio area waters of aquifers from 100 to $260 \mathrm{~m}$ deep present $\mathrm{Na} / \mathrm{Cl}$ ratios decreasing from 7.7 to 5.9 owing to a slight increase in water chlorinity. Increasing chlorinity with depth is a frequent feature of both fresh and saline waters of confined aquifers in other areas (KARACSONYI and SCHEUER, 1978).

An interesting feature of most of the waters of groups (c) and (d) is that they show a small but systematic positive thermal anomaly (1$5^{\circ} \mathrm{C}$ ) as compared with groundwaters of groups (a) and (b) at similar depths. This has been correlated (GoRGONI et al., 1982b) with deeper temperature patterns and available time periods for water-rock thermal equilibration.

Hydrological observations and the chemistry of waters from different zones of the sedimentary basin agree well with usual chemical trends of aquifers from recharge areas to confined zones (see e.g. Fontes and GarnIER, 1979). The progressive changes in water chemistry with increasing distance from the recharge areas may be attributed to rock-fluid interactions and to other processes causing cation exchanges or precipitation and sulphate reduction simultaneously.

On the basis of the chemical features of these waters and in consideration of the hydrodynamic properties of the aquifers in the lower plain zones, very long residence times were suspected, thus leading to hypothesize the existence of paleowaters in those zones.

\section{SAmpling AND ANALYTiCal Notes}

Five samples of group (c) and five samples of group (d) waters from the lower plain area were 
selected for oxygen and hydrogen isotope analyses. Four samples of group (b) from the same area and one of group (a) from the Apennine border (sample MA 1) were also analyzed. Fig. 3 presents some chemical features of the foregoing samples. As samples of group (c) present a quite uniform composition, they are represented on the diagram by a single area (deep sulfate-free freshwater). Samples CO 210, CO 211, PG 33A and $P G 33 B$ were submitted to repeated $O$ and $\mathrm{H}$ isotope analyses in different seasons.

${ }^{14} \mathrm{C}$ analysis was performed on two type (c) waters and on one of types (a), (b) and (d). For this analysis, the total dissolved carbon was precipitated using the technique recommended by the International Atomic Energy Agency (IAEA): addition of $\mathrm{FeSO}_{4}$ and precipitation with $\mathrm{BaCl}_{2}$ after basification with $\mathrm{NaOH}$, followed by collection of the precipitate for analysis.

Tritium content was tested on many samples of groups (a), (c) and (d) by liquid scintillation counting (detection limit: about 1 T.U.). All the isotope analyses were carried out in the Istituto Internazionale per le Ricerche Geotermiche of the Italian C.N.R., Pisa, Italy.

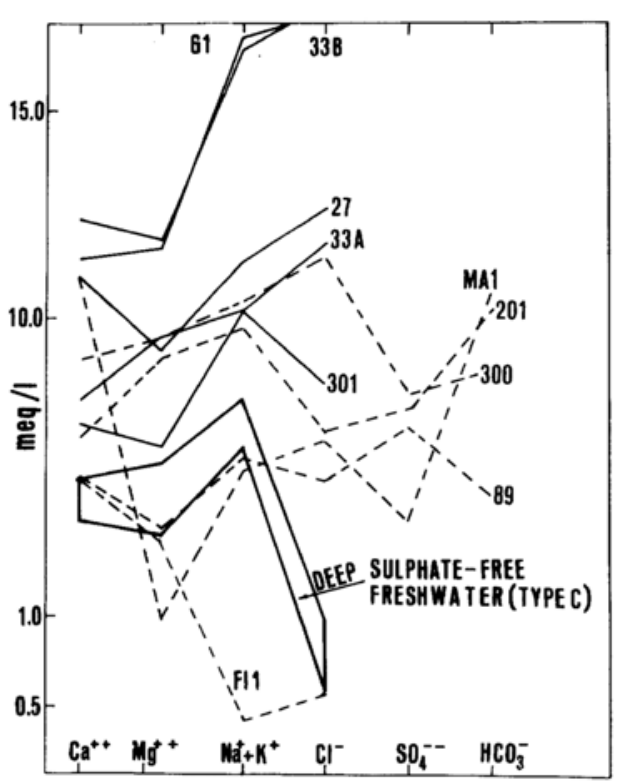

Fig. 3. Shoeller diagram showing the chemical composition of the water samples isotopically investigated. Bicarbonate content is given only for sulphate-bearing samples. Outlined area: compositioned field for samples CO 131, 142, 210, 211 and NO 116.

Table 2. Stable isotope composition and tritium content of some selected groundwaters in the Po basin

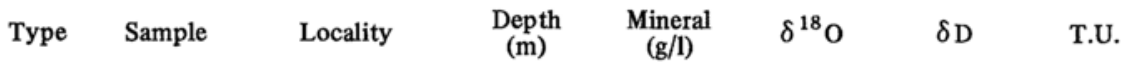

(a) Deep groundwaters near recharge areas

MA 1 Marzaglia 350

(b) Shallower waters

$\begin{array}{llll}\text { FI } & 1 & \text { Finale E. } & 30 \\ \text { RS } & 201 & \text { Rio Saliceto } & 10 \\ \text { CA } & 89 & \text { Cavezzo } & 10 \\ \text { MF } & 300 & \text { Massa F. } & 40\end{array}$

(c) Deep waters with slow circulation patterns

$\begin{array}{lllr}\text { NO } & 115 & \text { Novellara } & 80 \\ \text { CO } & 210 & \text { Corregio } & 100 \\ \text { CO } & 131 & \text { Correggio } & 116 \\ \text { CO } & 142 & \text { Correggio } & 158 \\ \text { CO } & 211 & \text { Correggio } & 260\end{array}$

(d) Sodium chloride waters

$\begin{array}{lllr}\text { G } & 1 & \text { Gavello } & 30 \\ \text { NO } & 27 & \text { Novi } & 40 \\ \text { PG } & \text { 33B } & \text { Poggio Rusco } & 40 \\ \text { PG } & \text { 33A } & \text { Poggio Rusco } & 130 \\ \text { MF } & \text { 301 } & \text { Massa F. } & 80\end{array}$

1.35

0.39

1.52

0.66

1.80

0.90

0.63

0.69

0.76

0.76

7.15

$$
-9.4
$$$$
-6.1
$$$$
<1
$$

$$
\begin{array}{r}
-10.4 \\
-8.3 \\
-8.5
\end{array}
$$$$
-8.1
$$

$\begin{array}{lll}-10.1 & -67.5 & <1 \\ -10.5 & -63.5 & <1 \\ -10.9 & -78.2 & <1 \\ -11.1 & -69.7 & <1 \\ -11.3 & -63.7 & <1\end{array}$




\section{RESULTS OF THE ISOTOPIC MEASUREMEMTS}

Oxygen and hydrogen isotope data and tritium content of the analyzed samples are reported in Table 2. The data show that most of deep bicarbonate and sodium chloride, both sulphate-free waters of groups (c) and (d) have a relatively homogeneous tendency to show low $\delta^{18} \mathrm{O}$ values, ranging from -10.1 to $-11.3 \%$. For the same samples, the $\delta \mathrm{D}$ values vary from -63.5 to $-78.2 \%$. $\mathrm{O}$ and $\mathrm{H}$ isotope composition for samples for which duplicate analyses were made does not show appreciable variations in time. Type (b) shallower waters are characterized, with the exception of sample FI 1, by distinctively higher $\delta^{18} \mathrm{O}$ values ranging from -8.1 to $-8.5 \%$. These values fall in the range of those (from -8.0 to $-9.0 \%$ ) usually found in waters of aquifers recharged by recent waters in the nearby Bologna area (CARLIN et al., 1975).

Finally, type (a) MA 1 sample, a deep sulphate-bearing water near the Apennine recharge area, presents an oxygen isotope composition intermediate $\left(\delta^{18} \mathrm{O}=-9.4 \%\right.$ ) between the two range of values previously indicated for the other water families.

Plots of $\delta^{18} \mathrm{O}$ against $\delta \mathrm{D}$ values (Fig. 4a) show that some waters tend to align on a trend coinciding with the precipitation line for the nearby Tuscany area (line 3). Other samples, however, and in particular some of group (c) bicarbonate waters depleted in ${ }^{18} \mathrm{O}$, tend to shift towards heavier hydrogen isotope compositions.

Figure $4 \mathrm{~b}$ illustrates the close relationships between oxygen isotope composition and chemical parameters for the various water types. Within bicarbonate waters, MA 1 and NO 115 samples plot between the groups of subsurface waters and deep-circulating waters, types (b) and (c) respectively. Oxygen isotope data for waters of Correggio area, all of type (c), show that their chemical stratification with depth is accompanied by a slight but significant decrease in ${ }^{18} \mathrm{O}\left(\delta^{18} \mathrm{O}\right.$ values from -10.5 to $-11.3 \%$ at depths varying from 100 to $260 \mathrm{~m}$ ).

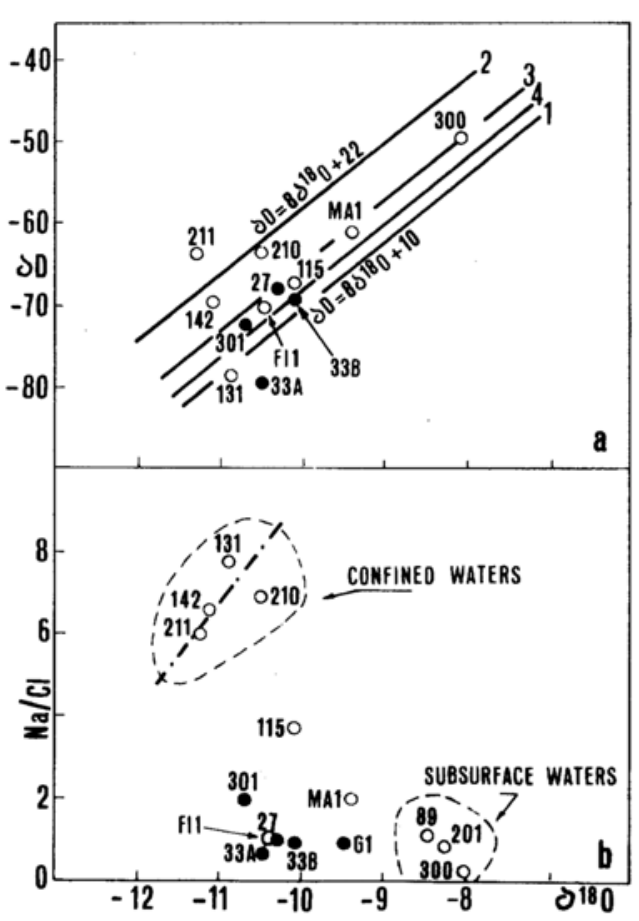

Fig. 4. A) $\delta^{18} O-\delta D$ relationship in the investigated groundwaters. Open circle: continental water; closed circle: sodium chloride water. Straight lines: isotope composition of actual precipitations.

1: oceanic; 2: Mediterranean; 3: Tuscany (CEI, 1969); 4: Maritime Alps, Northern Italy (BORTOLAMI et al., 1979).

B) $\delta^{18} \mathrm{O}-\mathrm{Na} / \mathrm{Cl}$ (equiv.) relationship for various types of groundwaters.

\section{Origin AND ChEMICAL Evolution of DEEP WATERS}

The meteoric precipitation lines 3 and 4 (Fig. 4a), referring respectively to zones to the south (Tuscany; CEI, 1969) and to the north (Piedimont; Bortolami et al., 1979) of the area under investigation, give the general trend of isotope composition of the meteoric waters involved in the present hydrological cycle. $\delta^{18} \mathrm{O}$ values between -7.0 and $-8.0 \%$ should be considered to be normal values for precipitations in most of the Po plain area (Bortolami et al., 1973). In recharge areas near the Apennine border the $\delta^{18} \mathrm{O}$ values of precipitation waters are close to $-7.0 \%$ (M.A.F., 1977). Slightly 
lower $\delta^{18} \mathrm{O}$ values, in the range -8.0 to $-9.0 \%$, should be considered for Apennine recharge areas up to $600 \mathrm{~m}$ high (GoNFIANTINI, unpublished data). Corresponding hydrogen isotope composition for the various sources of recharge can be deduced from Fig. 4a. CARLIN et al. (1975) have made an exhaustive study (including ${ }^{14} \mathrm{C}$ and tritium data) of surface and groundwaters of the Bologna area, very close to the area here investigated. Their results indicate that the $\delta^{18} \mathrm{O}$ values of groundwaters recharged by recent surface waters usually lie between -8.0 and $-9.0 \%$ and that they present significant variations in time corresponding to climatic and seasonal variations.

All these findings tend to reject decisevely the supposition that the deep circulating groundwaters here investigated belong to the present hydrological cycle. On the contrary, if we consider that in the present case the significant depletion in $\mathrm{D}$ and ${ }^{18} \mathrm{O}$ of the waters cannot be plausibly explained in terms of "inland" and "altitude" effects, we may suppose their recharge under climatic conditions much colder than the present ones.

However, these deductions are not so obvious considering that stable isotpe data alone may be poorly indicative in defining the origin of the circulating fluids and the paleoclimatology at their recharge (FonTES, 1980). This is particularly true in the case of waters in confined aquifers or generally with long residence times in the ground. It is well known, in fact, that groundwaters circulating in depths may have their chemical and isotope composition affected by a number of processes (water mixing, bacterial activity, solid phase precipitation, etc.). In our case, exchange processes with rocks or other fluids and water mixing phenomena seem to have played the major role in determining chemical and isotope features of the studied groundwaters.

Water mixing The salinity of the sodium chloride, type (d) waters is quite variable (Fig. 5) but the $\mathrm{Na} / \mathrm{Cl}$ ratios are very constant (Fig. $4 b)$. The mixing of saline waters with bicarbon- ate waters is therefore suggested (MALiuK and ARTEMCHUK, 1976). Sodium chloride waters are present as connate waters in sedimentary formations of marine derivation and are usually characterized by relatively heavy oxygen isotope composition compared to freshwaters (DEGENS et al., 1964; Clayton et al., 1966). Thus, the rough positive relationship between ${ }^{18} \mathrm{O}$ values and chlorinity shown by sodium chloride waters (Fig. 5, right side) is well explained. The relatively low $\delta^{18} \mathrm{O}$ values (ranging from -9.5 to $-10.7 \%$ ) found in type (d) sodium chloride waters suggest that the non-saline component must have very light oxygen isotope composition, i.e. that it is very similar to the bicarbonate waters of group (c) presumed to be present in confined aquifers in the lower plain areas.

A possible mixing line for bicarbonate waters of different origin is also plotted on Fig. 5 (left side). It may account for some samples (like MA 1 and NO 115) which have intermediate chemical and isotopic features between recent subsurface waters and possible paleowaters. The presumed mixing may be, however, only fortuitous on account of the few samples considered.

Exchange reactions Previous considerations on both cation and anion chemistry of the supposed paleowaters suggest significant postrecharge fluid-rock interactions. Two processes, i.e. precipitation of secondary phases (carbonates) and exchange reactions with clay minerals

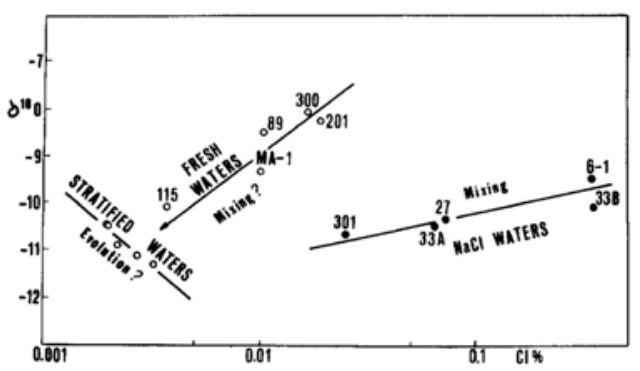

Fig. 5. $\delta^{18} \mathrm{O}$ vs. chlorinity for continental and sodium chloride waters and some tentative interpretations of their genetical relationships. 
should be considered. For example, the decrease in $\mathrm{Ca}$ with respect to waters near the recharge zone may be related to calcite deposition subsequent to a $\mathrm{CO}_{2}$-generating bacterial activity. The presence of secondary calcite in deep aquifers has been recently confirmed (PELLEGRINI and ZaVATTI, 1980). On the other hand, it is well known that calcium is easily exchanged by clay minerals thus its fixation in these minerals cannot be excluded. Also the very low potassium content of the supposed paleowaters is compatible with its retention in illite. Sodium is frequently considered (e.g. CARPENTER and MILLER, 1969) to be affected by clay minerals to a limited extent. In our case, if we admit that divalent cations $(\mathrm{Ca}$ and $\mathrm{Mg}$ ) were involved in exchange reactions wit clay minerals, sodium also must have been greatly affected by similar exchanges.

Chemical data on water samples here isotopically investigated seem to indicate that chlorinity decreases from recent subsurface waters to groundwaters of deep confined aquifers. However, this apparent negative relationship between chlorinity and depth and/or water residence time within the aquifers is probably fortuitous, as the subsurface water samples selected for the isotope study are peculiarly rich in chloride. The occurrence of subsurface waters of recent infiltration high in $\mathrm{Cl}$ is rather common in the lower plain area investigated. Their chlorinity is usually interpreted as correlated to well documented paleohydrological stages during which extensive rising towards the surface of deeper sodium chloride waters has occurred. The evaporation of these waters would have caused extensive saline impregnation in surface sediments that now affect the composition of recent waters.

Some authors (DICKEY, 1966; Dowgiallo and TONGIORGI, 1972; KARACSONY and SCHEUER, 1978) observed that in waters of confined aquifers chlorinity tends to increase with depth and residence time within the aquifers. This trend is respected in the supposed paleowaters of the Correggio area in which the increase of chlorinity with depth is accompanied by the significant lightening in oxygen isotope composition. As the paleorecharge areas for the considered aquifers have essentially been the same, a generalized deterioration of the climatic conditions with increasing age of the waters at different depths of the Correggio area should be deduced.

Possible effects of exchange reactions on stable isotope composition It is widely accepted that fluid-solid interactions and exchange reactions with other fluids may affect to some extent the stable isotope composition of groundwaters even at low temperatures. In aquifers recharged by recent waters the observed effects are insignificant because of the very low reaction rates but for waters maintained in the ground for long times the influence of exchange reactions may become important and must be discussed.

It is well known that waters in the deeper part of the underground hydrosphere are frequently enriched in oxygen-18 (CLAYTON et al., 1966; Friedman, 1965; Dowgiallo, 1973, 1978). This fact is commonly attributed to the isotopic exchange with mineral phases (carbonates, clay minerals) present in the water-bearing stratum. The extent of isotope exchange between water and common clay minerals has been experimentally investigated (e.g. O'NeIL and KHARAKA, 1976) but the results of these studies are not conclusive. Oxygen was constantly found poorly exchangeable. The extent of hydrogen isotope exchange seems to be also limited at low temperatures. In nature, however, waters always tend to concentrate deuterium relative to clay minerals (SAVIN and EPSTEIN, 1970; LAWRENCE and TAYLOR, 1971, 1972).

The process of crystallization of neogenetic minerals was found to affect the stable isotope composition of interstitial waters (LAWRENCE, 1974; LAWRENCE et al., 1975; FrIEDMAN and HARDCASTLE, 1974; RANDALl et al., 1979). In this case, the ${ }^{18} \mathrm{O}$ content of water tends to decrease while deuterium increases because of the respective fractionation. Thus, this process could 
explain the isotopic features of the supposed paleowaters of the investigated area of the Po plain. It should be noted, however, that the isotopic changes introduced in a similar way must be proportional to the rate of production of neogenetic minerals. In the case of waters circulating at low temperature in poorly reactive aquifers like those of the Po basin an extensive formation of neogenetic minerals seems to be highly unlikely. Thus, significant stable isotope fractionation should be excluded.

Some other processes (e.g. ultrafiltration, fluid-fluid exchanges) have been considered to affect the stable isotope composition of groundwaters. FERRARA et al. (1965) suggested that exchanges with $\mathrm{CO}_{2}$-rich fluids may deplete water in ${ }^{18} \mathrm{O}$. However, the depletion seems to be significant only at relatively high temperatures. Some authors reported deuterium enrichments in waters by exchanges with $\mathrm{H}_{2} \mathrm{~S}$ when present in considerable amounts or with hydrocarbons produced by bacterial activity. The traces of $\mathrm{H}_{2} \mathrm{~S}$ well evident in most of the supposed paleowaters suggest that the observed shift towards heavier hydrogen isotope compositions may be related to water-fluid exchanges. None of the considered processes, on the contrary, seems to account for the significant ${ }^{18} \mathrm{O}$ depletion of paleowaters when compared with waters of the present hydrological cycle. Oxygen isotope chemistry of groundwaters from the Po basin should, therefore, be considered essentially a conservative parameter which allows paleoclimatological implications.

\section{Paleoclimatological Implications}

The main conclusion derived from isotope chemistry is that the presumed paleowaters in the investigated area of the Po basin are meteoric waters infiltrated when the climatic conditions were significantly colder than at present. In order to verify whether the recognized paleohydrological cycle or cycles fit the accepted paleoclimatological patterns in the considered area, some ${ }^{14} \mathrm{C}$ age determinations were made on two type (c) supposed paleowaters, on one type (d) sodium chloride water, on one type (b) shallower water and on sample MA 1 which represents type (a) deep circulating waters in the area of actual recharge. All the analyzed samples were previously checked for tritium content and found virtually T-free (T.U. $<1)$. The ${ }^{14} \mathrm{C}$ values and calculated ages are reported in Table 3. The dissolved carbon content of the studied paleowaters is rather high and the traces of dissolved $\mathrm{H}_{2} \mathrm{~S}$ also may indicate mixing of $\mathrm{CO}_{2}$ liberated through a methane-producing bacterial activity (TAKAI, 1970; KoYAMA et al., 1973). Therefore the ${ }^{14} \mathrm{C}$ calculated ages may be poorly significant even though the correction for the contamination of dead carbon based on the $\delta^{13} \mathrm{C}$ values (Pearson and Hanshaw, 1970) is carried out (WIGLEY et al., 1978; FonTEs and GARNIER, 1979). Nevertheless, some comments may be made on the ages obtained. Two samples of the Correggio area from aquifers 158 and $260 \mathrm{~m}$ deep give apparent ages of 18,550 and $24,900 y r s$ respectively, but similar corrected ages (about 16,800yrs). Sample PG 33A gives an apparent age of about $25,000 y$ rs and a corrected age of $8,600 y r s$. Similar ages are presented for sample MA 1. From these data, one could deduce that the waters of the Correggio area are old waters reserved in closely confined aquifers while the samples of younger age (PG

Table 3. Carbon isotope data and ${ }^{14} \mathrm{C}$ radiometric ages in some selected groundwater samples

\begin{tabular}{lccccc} 
Type & Sample & \multicolumn{2}{c}{ Total dissolved carbon } & \multicolumn{2}{c}{ Radiometric age } \\
& & $\delta^{13}$ C PDB & ${ }^{14}$ C A, pmc & apparent & corrected \\
(c) & CO 142 & -16. & 10. & 18,550 & 16,700 \\
(c) & CO 211 & -7.3 & 4.5 & 24,900 & 16,800 \\
(d) & PG 33A & -2.7 & 4.7 & 24,550 & 8,600 \\
(b) & FI 1 & -4.1 & 24.8 & 11,200 & 500 \\
(a) & MA 1 & -6.6 & 9.9 & 18,600 & 9,700
\end{tabular}


33A, MA 1) are compatible with more recent recharges or with mixing between waters of different chemistries and/or ages. In any case, the inferred minimum ages should be of several thousands years. The very young age of FI 1 sample may be due to the infiltration of recent waters from the nearby Po river (Fig. 1) which collects even waters of the Alpine domain characterized by $\delta^{18} \mathrm{O}$ values slightly lower, up to about -9.5 or $-10.0 \%$ (CARLIN et al., 1975). This hypothesis is supported even by the chemistry of FI 1 sample which is very similar to subsurface or stream waters of the area and by considerations on hydrological features of the relative aquifer (e.g. depth and proximity to the local stream system).

A test of the significance of the obtained radiometric ages and of the paleoclimatological deductions derived from stable isotope data is provided by models of past climate available for the European and Mediterranean areas and, in particular, for northern Italy. Several models based on various evidences (biological, geophysical, etc.) and relative to different periods are given in literature. HAYs et al. (1976) have shown that the glaciation of the northern hemisphere has had a global effect, thus climatic trends in the different parts of Europe would be expected to follow a synchronous pattern. In NW Europe a general climatic deterioration following the Mid-Pleniglacial interstadial began about 24,000yrs BP (VAN DER HAMMEN et al., 1967; COOPE, 1977; ANDREWS and LEE, 1979). Climatic improvements following the Weichselian glaciation of NW Europe were synchronous and started about 14,000yrs BP.

For the northern Italy, biological findings (BoRTOLAMI et al., 1977; BERTOLANI MARCHETTI et al., 1980) show that glaciation pulsing seems to have been a decisive factor in determining the climatological suite in the late Quaternary, thus verifying the hypothesis that climatic variations in northern Italy were synchronous with those observed in the rest of Europe. Thus, the period from about 24,000 to 14,000 yrs BP must have been characterized by a strong climatic deterioration which caused significant changes in the isotopic composition of the waters participating to the contemporaneous hydrological cycles. An estimate of "average" temperature for this period in northern Italy may be deduced by similar estimates for the rest of Europe (VAN DER HAMMEN et al., 1967; COOPE, 1977) and it would have been lower by $5-6^{\circ} \mathrm{C}$ than at present. Such lowering of temperature may be responsible for the lower $\delta^{18} \mathrm{O}$ values of groundwaters of comparable age in confined aquifers in the Po plain.

Thus, chemical data, radiometric ages, stable isotope patterns and paleoclimatological informations seem to confirm the occurrence of the supposed paleowaters in the Po sedimentary basin.

Acknowledgements-The authors are grateful to Drs. S. NUTI and P. NOTO (Istituto Internazionale Ricerche Geotermiche, C.N.R., Pisa, Italy) for isotope determinations and suggestions. Thanks are due to Dr. R. GoNFIANTINI (I.A.E.A., Wien) for the critical reading of the manuscript. Work carried out within the project "Energy", subproject "Geothermal Energy" of the Italian C.N.R.

\section{REFERENCES}

ANDREWS, J. N. and LEE, D. J. (1979) Inert gases in groundwater from the Bunter sandstone of England as indicators of age and paleoclimatic trends. $J$. Hydrology 41, 233-252.

BERTOLANI MARCHETTI, D., ACCORSI, C. A., BANDINI MAZZANTI, M. and FoRLANI, L. (1980) Le ricerche palinologiche nell'illustrazione dell'ambiente naturale bolognese. Natura e Montagna 3, 33-57.

Bortolami, G. C., Braga, G., Colombetti, A., Dal PrÀ, A., FranCANI, V., FranCAVILla, F., GIULIANo, G., Manfredini, M., Pellegrini, M., PETRUCCI, F., POZZI, R. and STEFANINI, S. (1978) Hydrogeological features of the Po Valley (Northern Italy). In Hydrogeology of great sedimentary basins, IAHS-AISH, Hungarian Geol. Inst., Budapest, 304321.

Bortolami, G. C., Fontes, J. Ch., Markgraf, V. and SALIEGE, J. F. (1977) Land, sea and climate in the northern Adriatic region during the late Pleistocene and Holocene. Paleogeog. Palaeoclim. Palaeoecol. 21, 139-156.

Bortolami, G. C., Fontes, J. Ch., and PANichi, C. (1973) Isotopes du milieu et circulation dans les aquifères du sous-sol Vénetien. Earth Planet. Sci. 
Lett. 19, 154-167.

Bortolami, G. C., RicCI, B., Susella, G. F. and ZUPPI, G. M. (1979) Isotope hydrology of Val Corsaglia, Maritime Alps, Piedimont, Italy. In Isotope Hydrology 1978, Vol. I, I.A.E.A., Wien, $327-350$.

Carlin, F., Magri, G., Cervellati, A. and GoNFIANTINI, R. (1975) Use of environmental isotopes to investigate the interconnections between the Reno river and groundwater (northern Italy). In Isotope ratios and pollutant source and behaviour indicators, I.A.E.A., Wien, 179-194.

CARPENTER, A. B. and Miller, J. C. (1969) Geochemistry of saline subsurface water, Saline County (Missouri). Chem. Geol. 4, 135-167.

CEI, C. (1969) Studio isotopico sulle sorgenti termominerali della Toscana ad est del M. Amiata. PhD Thesis, Università di Pisa (unpublished).

Clayton, R. N., Friedman, I., GRAF, D. L., MAYEda, T. K., MEENTS, W. F. and SHIMP, N. F. (1966) The origin of saline formation waters. Isotopic composition J. Geophys. Res. 71, 3869-3882.

COOPE, G. R. (1977) Fossil Coloepteran assemblages as sensitive indicators of climatic changes during the Devensian (last) cold stage. Philos. Trans., R. Soc. London, Ser. B, 280, 313-322.

DEGENS, E. T., HUNT, J. M., REUTER, J. H. and REED, W. E. (1964) Data on the distribution of amino acids and oxygen isotopes in petroleum brine waters of various geologic ages. Sedimentology 3, 199-211.

DIKEY, P. A. (1966) Patterns of chemical composition in deep subsurface waters. Bull. Am. Assoc. Petrol. Geol. 50, II, 2472-2478.

DoWGIALLO, J. (1973) Results of oxygen and hydrogen isotopic investigations in groundwaters of South Poland. Geolog. Inst. Bull. 277, pp. 319 (in Polish).

Dowgiallo, J. (1978) Stable isotopes as indicators of the origin and zonal affiliation of deep-seated groundwaters in sedimentary basins. In Hydrogeology of great sedimentary basins, LAHS-AISH, Hungarian Geol. Inst., Budapest, 562-569.

Dowgiallo, J. and TONGIORGI, E. (1972) The isotopic composition of oxygen and hydrogen in some brines from the Mesozoic in the North-West Poland. Geothermics 1, 67-69.

Ferrara, G. C., Gonfiantini, R. and Panichi, C. (1965) La composizione isotopica del vapore di alcuni soffioni di Larderello e dell'acqua di alcune sorgenti e mofete della Toscana. Atti Soc. Tosc. Sc. Nat., Serie A, 72, 570-588.

FONTES, J. CH. (1980) Stable isotopes in palaeowaters. In Stable Isotope Hydrology, J. R. GAT and R. GONFIANTINI Editors, Monography IAEAUNESCO.

FONTES, J. CH. and GARNIER, J. M. (1979) Deter- mination of the initial ${ }^{14} \mathrm{C}$ activity of the total dissolved carbon: a review of the existing models and a new approach. Water Res. Research 15, 399-413.

FRIEDMAN, I. (1965) Interstitial water from deep sea sediments. J. Geophys. Res. 70, 4066-4082.

Friedman, I. and HARDCASTLE, K. (1974) Deuterium in interstitial waters from Red Sea cores. In Initial Reports of the Deep Sea Drilling Project 23, 969-982. U.S. Government Printing Office, Washington.

GASPERI, G. and Pellegrini, M. (1969) Le falde acquifere della pianura compresa fra i fiumi Secchia, Panaro e Po (province di Modena e Mantova). Atti Uff. $I^{\circ}$ Conv. Naz. di studi sui problemi della Geologia Applicata, Milano, 3-10.

GoRGONI, C., SighinOlFi, G. P. and MARTINELli, G. (1982a) Radon distribution in groundwaters of the Po sedimentary basin (Italy). Chem. Geol., in press.

Gorgoni, C., SighinOlfi, G. P. and MARTINELli, G. (1982b) Geochimica e modalità di circolazione di acque sotterranee in alcune aree della Pianura Padana. Atti II Sem. Inf. Energia Geotermica, C.N.R., PEG Ed., Rome, in press.

HAYS, J. D., IMBRIE, J. and SHACKLETON, N. J. (1976) Variations in the earth's orbit: pacemaker of the ice ages. Science 194, 1121-1132.

KARACSONYI, S. and SCHEUER, GY. (1978) Physical and chemical characteristics of confined waters in peripheric territories. In Hydrogeology of great sedimentary basins. IAHS-AISH, Hungarian Geol. Inst., Budapest, 577-589.

Koyama, T., NiKaIDO, M., TOMINo, T. and HaYaKaWA, H. (1973) Decomposition of organic matter in lake sediments. In Proceedings of a symposium on hydrogeochemistry and biochemistry, Tokyo, 512535. The Clarke Co.

LAWRENCE, J. R. (1974) Stable oxygen and carbon isotope variations in the pore waters, carbonates and silicates, sites 225 and 228, Red Sea. In Initial Reports of the Deep Sea Drilling Project 23, 939-945. U.S. Govern. Print. Office, Washington.

LAWRENCE, J. R., GIESKES, J. M. and BROECKER, W. S. (1975) Oxygen isotope and cation composition of DSDP pore waters and alteration of layer II basalt. Earh Planet. Sci. Lett. 27, 1-10.

LAWRENCE, J. R. and TAYLOR, H. P., JR. (1971) Deuterium and oxygen-18 correlation: clay minerals and hydroxides in Quaternary soils compared to meteoric waters. Geochim. Cosmochim. Acta 35, 993-1003.

LAWRENCE, J. R. and TAYLOR, H. P., JR. (1972) Hydrogen and oxygen isotope systematics in weathering profiles. Geochim. Cosmochim. Acta 36, 13771393.

M.A.F. (Ministero dell'Agricoltura e delle Foreste, 
Roma) (1977) Studi e ricerche metodologiche per il ravvenamento artificiale del conoide del fiume Marecchia a scopo idropotabile e irriguo, Rimini, $21 \mathrm{pp}$.

MALIUK, G. A. and ARTEMCHUK, V. G. (1976) D/H and ${ }^{18} \mathrm{O} /{ }^{16} \mathrm{O}$ ratios of formation waters as indicators of water-rock interaction. In Proc. Int. Symp. on water-rock interaction, J. CADEK and T. PACES, Editors, Prague, pp. 348-355.

O'NEIL, J. R. and KHARAKA, Y. K. (1976) Hydrogen and oxygen isotope exchange reactions between clay minerals and water. In Proc. Int. Symp. on waterrock interaction, J. CADEK and T. PACES, Editors, Prague, pp. 356-362.

PEARSON, J. J. and HANSHAW, B. B. (1970) Sources of dissolved carbonate species in groundwater and their effects on carbon-14 dating. In Isotope Hydrology, I.A.E.A., Wien, pp. 271-286.

Pellegrini, M. and ZaVATTI, A. (1980) Il sistema acquifero sotterraneo fra i fiumi Enza, Panaro e Po: alimentazione delle falde e scambi fra falde, correlazioni idrochimiche. Quaderni Ist. Ric. sulle Acque, C.N.R., 51, 205-217.

RANDALL, S. M., LAWRENCE, J. R. and GIESKES, J. M. (1979) Interstitial water studies, sites 385 and 387. In Initial Reports of the Deep Sea Drilling
Project 43, 669-682. U. S. Government Printing Office, Washington.

SAVIN, S. M. and EPSTEIN, S. (1970) The oxygen and hydrogen isotope geochemistry of clay minerals. Geochim. Cosmochim. Acta 34, 25-42.

SighiNOLFI, G. P., GoRGONI, C. and MARTINELli, G. (1979) Studio di acque termicamente anomale della bassa pianura emiliana. Atti $\Gamma^{\circ}$ Sem. Inf. Energia Geotermica, C.N.R., PEG Ed., Rome, pp. 431440.

TAKAI, Y. (1970) The mechanism of methane fermentation in flooded paddy soil. Soil Sci. Plant Nutr. $16,238-244$.

VAN DER HAMmen, T., MAARLEVeld, G. C., Vogel, J. C. and ZAGWIJN, W. H. (1967) Stratigraphic climatic succession and radiocarbon dating of the last glacial in the Netherlands. Geol. Mijnbouw 46, 79-95.

WHITE, D. E. (1965) Saline waters of sedimentary rocks. Am. Assoc. Petrol. Geol., Fluids in subsurface environments, Symp. Mem. 4, 342-366.

Wigley, T. M. L., Plummer, L. N. and Pearson, F. J., JR. (1978) Mass transfer and carbon isotope evolution in natural water systems. Geochim. Cosmochim. Acta 42, 1117-1139. 